\title{
A new species of the sauropsid reptile Nothosaurus from the Lower Muschelkalk of the western Germanic Basin, Winterswijk, The Netherlands
}

\author{
Nicole Klein and Paul C.H. Albers \\ Acta Palaeontologica Polonica 54 (4), 2009: 589-598 doi: http://dx.doi.org/10.4202/app.2008.0083
}

A nothosaur skull recently discovered from the Lower Muschelkalk (early Anisian) locality of Winterswijk, The Netherlands, represents at only $46 \mathrm{~mm}$ in length the smallest nothosaur skull known today. It resembles largely the skull morphology of Nothosaurus marchicus. Differences concern beside the size, the straight rectangular and relative broad parietals, the short posterior extent of the maxilla, the skull proportions, and the overall low number of maxillary teeth. In spite of its small size, the skull can not unequivocally be interpreted as juvenile. It shows fused premaxillae, nasals, frontals, and parietals, a nearly co-ossified jugal, and fully developed braincase elements, such as a basisphenoid and massive epipterygoids. Adding the specimen to an existing phylogenetic analysis shows that it should be assigned to a new species, Nothosaurus winkelhorsti sp. nov., at least until its juvenile status can be unequivocally verified. Nothosaurus winkelhorsti sp. nov. represents, together with Nothosaurus juvenilis, the most basal nothosaur, so far.

Key words: Sauropterygia, Nothosaurus, ontogeny, Anisian, The Netherlands.

Nicole Klein [nklein@uni-bonn.de], 1Steinmann Institute, Paleontology, University of Bonn, Nußallee 8, 53115 Bonn, Germany; Paul C.H. Albers [palbers@ xs4all.nl], Naturalis, Leiden, The Netherlands. Darwinweg 2, 2333 CR Leiden, The Netherlands;

This is an open-access article distributed under the terms of the Creative Commons Attribution License (for details please see creativecommons.org), which permits unrestricted use, distribution, and reproduction in any medium, provided the original author and source are credited. 
FoF Full text $(596.3 \mathrm{kB})$ 